\title{
Teams Games Tournament untuk Meningkatkan Kemampuan Mengenal Lambang Bilangan pada Anak Usia Dini
}

\author{
Indah Setianingrum $^{1 凶}$, Nur Azizah $^{2}$ \\ Pendidikan Guru Pendidikan Anak Usia Dini Universitas Negeri Yogyakarta, Indonesia(1,2) \\ DOI: $\underline{10.31004 / o b s e s i . v 6 i 1.1268}$
}

\begin{abstract}
Abstrak
Teams Games Tournament (TGT) adalah tipe pembelajaran kooperatif yang menempatkan siswa dalam kelompok kecil beranggotakan 5 sampai 6 siswa yang memiliki kemampuan, jenis kelamin dan ras berbeda. Penelitian ini bertujuan mengembangkan model pembelajaran kooperatif tipe TGT untuk anak usia 4-5 tahun. Penelitian ini mengadaptasi pendekatan Reseach and Development (RnD) dengan menggunakan model ADDIE, yang mencakup tahap analyze, design dan Develop. Penelitian menggunakan 3 tahap karena kondisi pandemi Covid19, menjadikan sulitnya mendapatkan izin penelitian di lembaga untuk melanjutkan ke tahap selanjutnya. Penilaian ahli materi menunjukkan koefisien $84,37 \%$ yang memiliki arti sangat layak. Selain itu, penilaian ahli media menunjukkan koefisien $87,17 \%$ yang memiliki arti sangat layak. Penelitian ini menyimpulkan bahwa produk penelitian berupa model pembelajaran kooperatif tipe TGT untuk anak usia 4-5 tahun memiliki keberterimaan berdasarkan penilaian ahli materi dan media. Hasil penelitian ini merekomendasikan untuk mengidentifikasi secara empiris keefektifan model pembelajaran kooperatif tipe TGT untuk anak usia 4-5 tahun.

Kata Kunci: model pembelajaran kooperatif, tipe teams games tournament, kemampuan mengenal lambang bilangan
\end{abstract}

\begin{abstract}
Teams Games Tournament (TGT) is a type of cooperative learning that places students in small groups of 5 to 6 students with different abilities, genders, and races. This study aims to develop a TGT type of cooperative learning model for children aged 4-5 years. This study adopts the Research and Development $(\mathrm{RnD})$ approach using the ADDIE model, including analyzing, designing, and developing stages. The research used three steps due to the conditions of the Covid-19 pandemic, making it difficult to get research permits at institutions to proceed to the next stage. The material expert's assessment shows a coefficient of $84.37 \%$, which means very feasible. In addition, the media expert's estimate shows a coefficient of $87.17 \%$, which means very feasible. This study concludes that the research product in the form of the TGT cooperative learning model for children aged 4-5 years has acceptance based on the assessment of material and media experts. The results of this study recommend identifying empirically the effectiveness of the TGT type of cooperative learning model for children aged 4-5 years.
\end{abstract}

Keywords: cooperative learning model, the type of teams games tournament, the ability to recognize number symbols

Copyright (c) 2021 Indah Setianingrum, Nur Azizah

$\square$ Corresponding author :

Email Address : email koresponden@gmail.com (alamatkoresponden) Received 16 April 2021, Accepted 6 May 2021, Published 18 May 2021 


\section{PENDAHULUAN}

Masa usia dini merupakan masa emas perkembangan atau biasa disebut dengan golden age, pada masa-masa usia 0-5 tahun (Carpenter, 2012; Penn, 2014). Pada masa inilah anak mengalami pertumbuhan dan perkembangan yang paling cepat. Pernyataan tersebut sejalan dengan pendapat Berg (dalam Sujiono,2009) yang menyatakan bahwa pada masa ini pertumbuhan dan perkembangan dalam berbagai aspek sedang mengalami masa yang cepat dalam rentang perkembangan hidup manusia (Black dkk., 2017; Britto dkk., 2017; Sujiono \& Sujiono, 2012). Masa usiadiniinimemerlukan stimulus yang secara simultan untuk mendukung perkembangan anak secara maksimal (Olusanya dkk., 2017).

Memasuki pendidikan dasar diperlukan persiapan-persiapan untuk meningkatkan kemampuan dan kreativitas sesuai dengan tahapan perkembangan anak melalui kegiatan pengembangan bidang kemampuan dasar. Beberapa kemampuan dasar pada anak usia dini meliputi kemampuan fisik motorik, kognitif, bahasa, sosial emosional, serta nilai-nilai agama dan moral (Prasetiawan \& Supriyanto, 2016; Saloko dkk., 2019). Melalui program Pendidikan pada anak usia dini, diharapkan berbagai kemampuan dasar anak dapat berkembang optimal dan dapat menunjang perkembangan optimal di masa yang akan datang.

Salah satu aspek yang dikembangkan pada anak adalah aspek kognitif (Kogan, 2013). Perkembangan kemampuan kognitif memberikan sumbangan yang besar terhadap kemampuan bahasa, kemampuan emosional, kemampuan moral, bahkan kemampuan agama (Sit, 2015). Dalam perkembangan kognitif, salah satunya yaitu matematika awal untuk anak usia dini. Kognitif adalah proses berpikir, yaitu kemampuan individu untuk menghubungkan, menilai, dan mempertimbangkan suatu kejadian atau peristiwa(Lazarus dkk., 2012; Susanto, 2011). Dalam perkembangan anak kognitif merupakan perkembangan yang sangat penting, karena semua perkembangan anak melibatkan perkembangan kognitif. Proses perkembangan kognitif berhubungan dengan tingkat kecerdasan yang menandai seseorang dengan berbagai minat terutama sekali ditujukan kepada ide-ide dan belajar.

Perkembangan kognitif anak usia dini dapat dikembangkan melalui kegiatan seperti mengenal tekstur, pencampuran warna, matematika sederhana, mengelompokkan benda, memasangkan benda. Salah satunya adalah matematika, matematika yang paling sederhana untuk anak usia dini. Literatur lain menyebutkan bahwa, mengurutkan angka merupakan salah satu kemampuan kognitif siswa yang rawan terjadi masalah (Al Mubarok \& Amini, 2019). Menurut Gassel \& Amatruda, pada usia 4-5 tahun yaitu masa belajar matematika (Susanto, 2011). Pada usia ini anak mulai mengenal angka dari angka 1-10. Anak mulai belajar mengurutkan, menyebutkan, melengkapi, dan memasangkan jumlah benda.

Dalam tahap ini anak mulai belajar matematika sederhana, misalnya menyebutkan bilangan, menghitung urutan bilangan walaupun masih keliru urutannya, dan penguasaan sejumlah kecil dari benda-benda. Lambang bilangan atau angka perlu dikenalkan sebagai dasar bagi anak untuk berhitung. Lambang bilangan adalah suatu ilmu tentang struktur yang berhubungan dengan baik, artinya berhitung merupakan ilmu yang terhubungkan dengan penelaah bentuk, struktur-struktur abstrak dan hubungan diantara hal-hal tersebut dalam berhitung terorganisasikan dengan baik, sistematis dan logis (Sriningsih, 2009). Kemampuan mengenal lambang bilangan yaitu meliputi kemampuan anak dalam mengenal lambang bilangan, menunjukkan lambang bilangan, mengetahui jumlah sesuai dengan banyaknya benda, dan menghubungkan dengan benda nyata. Beberapa penelitian menunjukkan bahwa kemampuan mengenal bilangan masih menjadi permasalahan pada diri anak usia dini. Penelitian di salah satu Pendidikan Anak Usia Dini di Kabupaten Tasikmalaya menunjukkan bahwa anak yang memiliki kemampuan yang baik dalam mengenal lambang bilangan adalah sebanyak $27,8 \%$, dan sisanya perlu ada upaya untuk mengembangkannya (Sumardi dkk., 2017). Penelitian selanjutnya menunjukkan bahwa kemampuan anak dalam mengenal bilangan cenderung sangat rendah dan membutuhkan upaya kreatif untuk membantu mengembangkannya (Hasibuan, 2020). Penelitian selanjutnya di Jambi menunjukkan bahwadari 45 anakusiadini, satu di antaranya memiliki kemampuan yang 
sangat tidak baik dalam mengenal bilangan, dan 8 di antaranya memiliki kemampuan yang tidak baik dalam mengenal lambang bilangan(Suciyati \& Masrita, 2020).

Lambang bilangan perlu diperkenalkan sejak awal terutama pada usia 4-6 tahun, untuk membantu pertumbuhan dan perkembangan jasmani dan rohani anak agar memiliki kesiapan untuk memasuki pendidikan lebih lanjut. Memperkenalkan bilangan pada perkembangan anak usia dini seyogyanya dilakukan melalui aktivitas bermain dalam kehidupan sehari-hari dan bersifat alamiah. Melalui bermain anak merasa senang, nyaman, dan anak akan belajar tentang kehidupan, melatih keberanian sehingga menumbuhkan rasa kepercayaan diri, serta belajar menghargai teman sesamanya. Bermain merupakan dunia anak-anak, tempat dengan siapa mereka bertemu, beraktivitas dan berkreativitas. Walaupun mereka tidak saling mengenal, mereka berkumpul bersama dan bermain (Abidin, 2009). Selain itu menggunakan media yang menarik dapat membantu dalam meningkatkan kemampuan mengenal lambang bilangan. Seperti penelitian yang dilakukan di Klaten, menyatakan bahwa melalui penggunaan media yang menarik dan dapat merangsang stimulasi perkembangan kognitif anak. salah satunya dengan menggunakan media kartu angka bergambar (Syahrida, dkk: 2016). Sselain itu,menggunakan model pembelajaran yang menarik dapat meningkatkan kemampuan mengenal lambang bilangan. Sepeti penelitian yang dilakukan di Singaraja, mengatakan bahwa untuk meningkatkan kemampuan mengenal lambang bilangan pada anak perlu dilakukan suatu model pembelajaran dan media yang menarik untuk anak. Salah satu model pembelajaran kooperatif yang dapat diterapkan untuk mengembangkan kemampuan mengenal lambang bilangan adalah pembelajaran Number Head Together (Wulandari, dkk, 2014).

Berdasarkan data observasi awal yang dilakuan pada bulan Januari 2021 di salah satu TK di Magetan yaitu di RA Al Amanah, dengan jumlah 20 anak. Diperoleh fakta empiris yang menunjukkan bahwa anak-anak Kelompok A (4-5 tahun), menunjukkan bahwa kemampuan anak dalam mengenal lambang bilangan masih rendah. Seperti yang dinyatakan oleh Jordan, dkk (2009) bahwa kemampuan mengenal lambang bilangan pada Taman Kanak-kanak berpengaruh pada matematika kelas 1-3 pada tingkat sekolah dasar. Jika pada TK kemampuan lambang bilangan rendah, maka kemampuan pada sekolah dasar kelas 1-3 akan berpengaruh. Pernyataan tersebut dibuktikan dengan ditemukannya 16 anak kurang mampu menyebutkan bilangan 1-10, 4 anak belum mengetahui lambang bilangan. Hal tersebut terlihat pada saat anak menuliskan lambang bilangan setelah membilang banyak benda sesuai penjelasan guru. Dan ketika anak menghubungkan jumlah benda dan menariknya dengan menarik garis ke bilangan yang sesuai, ditemukan banyak anak yang belum benar. Sebagai contoh anak sudah membilang dengan benar gambar dengan jumlah 7, tapi menarik garisnya dihubungkan ke angka 5. Seperti penelitian yang dilakukan oleh Wahyuni (2017), menyatakan bahwa kemampuan mengenal lambang bilangan Kelompok Bermain Bina Ana Prasa III samarinda masih rendah. Dengan dibuktikannya anak dalam membedakan lambang bilangan kadang masih terbalik bilangan 6 dianggap bilangan 9 dan sebaliknya. Dan disimpulkan bahwa $40 \%$ anak belum berkembang, 33\% mulai berkembang, 20\% berkembang sesuai harapan, dan $7 \%$ berkembang sangat baik. Data pada penelitian ini diambil melalui angket dan observasi oleh guru. Angket berisikan indikator yang telah divalidkan oleh ahli instrumen. Kisi-kisi intrumen yang digunakan untuk kemampuan mengenal lambang bilangan meliputi mengurutkan angka, menyebutkan angka, menunjukkan angka, melengkapi angka, dan memasangkan angka. Sedangkan observasi dilakukan oleh guru untuk menilai dari indikator yang telah ditetapkan.

Guru melihat adanya kemampuan anak yang masih rendah, dengan melakukan berbagai tindakan agar kemampuan mengenal lambang bilangan dapat optimal. Guru memberikan berbagai kegiatan seperti memberikan bantuan pada saat melakukan kegiatan. Bantuan yang dilakukan oleh guru meliputi, memberikan arahan agar anak dapat menyelesaikan kegiatan. Tetapi hal tersebut tidak dapat menunjang keoptimalan pada kemampuan mengenal lambang bilangan. Seperti penelitian yang dilakukan di Samarinda 
bahwa proses pembelajaran kognitif dalam mengenal lambang bilangan 1-10 pada pembelajaran hanya menggunakan media atau sumber belajar yang kurang menarik bagi anak, hal ini membuat anak-anak kurang semangat dalam belajar sehingga anak-anak hanya sekedar mengahafal tanpa tahu satu persatu bilangan 1-10 (Wahyuni, 2017). Kemudian penelitian yang dilakuakn di Bangkinang mengatakan bahwa masih terbatasnya dalam penggunaan media yang digunakan oleh guru pasa saat proses belajar mengajar, sebagian besar kegiatan mengenal lambang bilangan masih menggunakan LKA, buku tulis, papan tulis, dan jarang menggunakan APE (Rianti, 2016).

Dengan adanya permasalahan kemampuan mengenal lambang bilangan maka peneliti menawarkan model pembelajaran yang menarik, yaitu model pembelajaran kooperatif tipe teams games tournamen (TGT). Pembelajaran merupakan proses keterlibatan anak dalam kegiatan akademik untuk mendapatkan pengetahuan. Pembelajaran dapat menentukan terwujudnya sikap danperilaku anak sehingga keterlibatan anak dalam pembelajaran dapat menimbulkan kegigihan, perhatian, keinginan, kemandirian dan semangat untuk belajar (Musu-Gillette et al., 2015). Teori dari piaget dan vygotsky yang disebut dengan pendekatan konstruktivismemenegaskan bahwa perkembangan kognitif dan sosial menjadi tujuan dari pendidikan anakusia dini (Chambers et al., 2016; Martin et al., 2005). Teori ini meyakini bahwa pengetahuan tidak diperoleh secara pasif tetapi dengancara anak yang aktif melakukan eksplorasi maupun eksperimen sehingga dapat membangun pengetahuannya sendiri(Khalid \& Azeem, 2012; Martin, 2012).

Beberapa penelitian menunjukan bahwa model pembelajaran kooperatif tipe TGT dapat meningkatkan perkembangan anak. Salah satu penelitian di Singaraja menunjukan bahwa tipe TGT berbantuan media kotak pos geometri pada anak Kelompok B Semester II Tahun Pelajaran 2013/2014 Di TK Tunas Mekar sebesar 19,25\% (Dewi et al., 2014). Penelitian selanjutnya di Malang menunjukkan bahwa terdapat perbedaan peningkatan pengetahuan yang signifikan antara kelompok TGT dan kelompok ceramah $(\mathrm{p}<0,05)$. Peningkatan ratarata nilai kelompok TGT lebih tinggi 2,93\% dibandingkan kelompok ceramah (Safitri et al., 2014). TGT adalah pembelajaran yang dilakukan dengan cara siswa berlomba sebagai wakil dari tim mereka dengan anggota tim lain dengan tingkat akademik yang berbeda-beda (Slavin, 2010; Wyk, 2011). Dengan adanya model pembelajaran yang menggunakan pertandingan, anak akan merasa tertantang akan pertandingan tersebut. Model pembelajaran kooperatif tipe TGT mempunyai 5 komponen utama, yaitu penyajian kelas, kelompok, game, turnament, dan penghargaan (Shoimin, 2014). Anak akan menggali pertandingan agar memenangkan pertandingannya. Pada penelitian menambahkan evaluasi setelah pertandingan selesai, untuk mengetahui dimana kesalahan pada setiap kegiatan. Model pembelajaran kooperatif tipe TGT dapat menjadikan referensi guru agar pembelajaran menarik, tidak mononton, dan membosankan.

Dengan adanya pemasalahan yang diuraikan, maka peneliti memfokuskan penelitian ini dengan mengembangkan model pembelajaran kooperatif tipe teams games tournament untuk meningkatkan kemampuan mengenal lambang bilangan anak usia 4-5 tahun. Hanya saja pada penelitian ini mengembangkan sampai tahap pengembangan instrumen, belum sampai tahap implementasi atau uji coba lapangan dan evaluasi. Pada penelitian ini ada pembaruan pada sintaks TGT, yaitu penambahan tahap evaluasi yang terletak pada akhir turnamen. Jika pada penelitian-penelitian sebelumnya (Zughoiiyah, dkk, 2015) menggunakan sintaks yang meliputi : (1) penyajian, (2) membagi kelompok, (3) mencoba permainan, (4) pertandingan. Tetapi pada penelitian ini ditambahkan tahap yang kelima yaitu evaluasi pertandingan yang telah dilakukan.

\section{METODOLOGI}

Jenis penelitian pada penilitian ini menggunakan penelitian pengembangan yang bertujuan untuk mengesahkan sebuah produk dalam bidang pendidikan. Produk dalam penelitian ini adalah model pembelajaran kooperatif tipe teams games tournament untuk 
meningkatkan kemampuan mengenal lambang bilangan anak usia 4-5 tahun. Desain peneliian ini menggunakan model ADDIE yang terdiri dari lima tahap yaitu Analyze, Design, Develop, Implement dan Evaluate. Langkah-langkah penelitian pengembangan ADDIE dapat dilihat pada bagan 1 sebagai berikut:

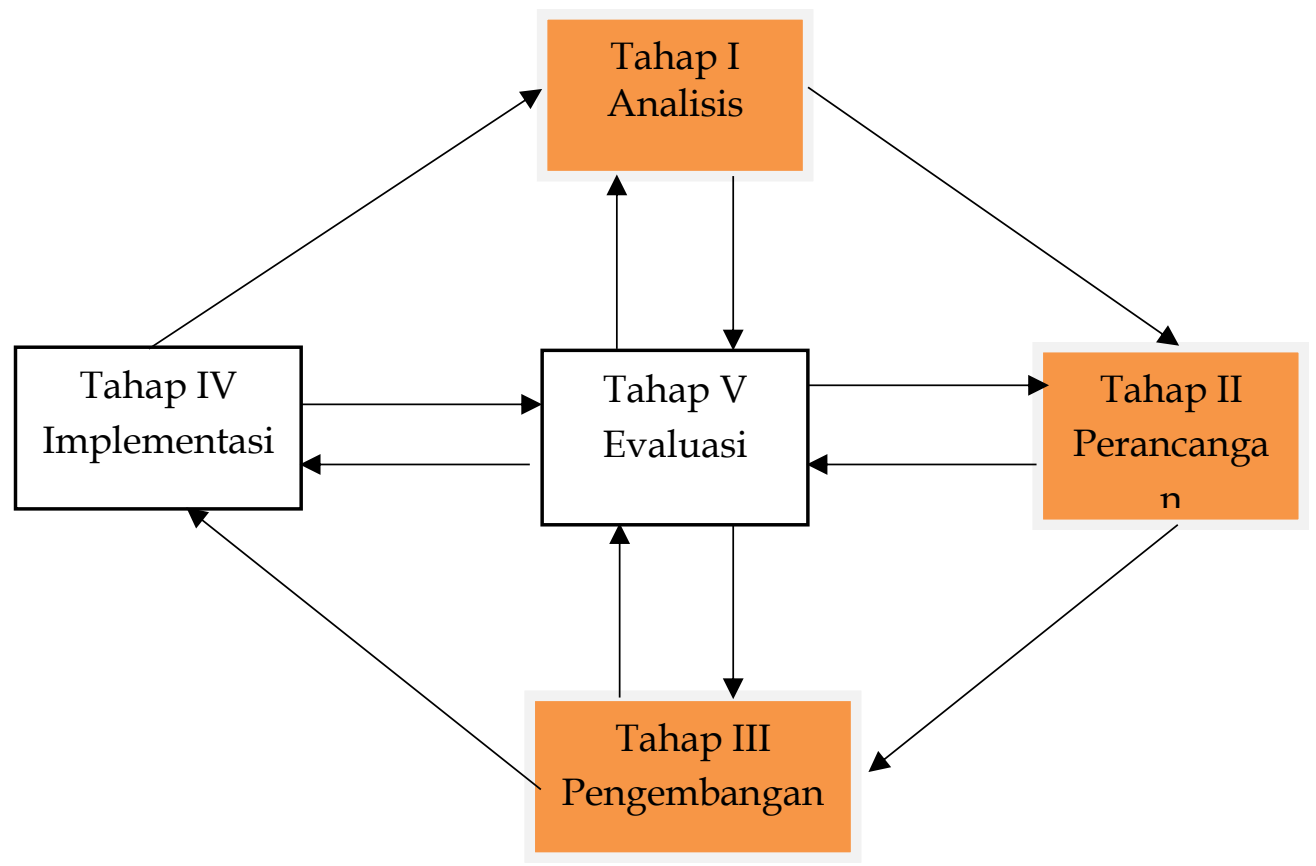

Bagan 1 Langkah-langkah ADDIE

Akan tetapi, pada penelitian ini tahap-tahap memfokuskan pada (1) menganalisis permasalahan anak tentang kemampuan mengenal lambang bilangan serta kegiatan yang dilakukan di TK, (2) merancang sebuah kegiatan, instrumen, dan buku panduan mengenai mengenal lambang bilangan menggunakan model pembelajaran kooperatif tipe TGT, dan (3) melakukan uji validasi dengan ahli materi dan media untuk mengidentifikasi keberterimaan produk. Penelitian ini hanya pada tahap pengembangan dikarenakan untuk melanjutkan tahap selanjutnya tahap implementasi membutuhkan lembaga TK dan pembelajaran langsung untuk anak. akan tetapi, untuk mendapatkan izin penelitian di lembaga TK sangat sulit, karena kondisi saat ini masih pandemi Covid-19. Sedangkan untuk pembelajaran TGT ini membutuhkan pembelajaran langsung dan tidak bisa menggunakan proses pembelajaran daring. Seperti penelitian yang dilakukan di Jakarta, bahwa peneliti hanya melakukan pada tahap analisis, desain, dan pengembangan karena penelitian hanya sampai pada tahap peenyempurnaan produk pengembangan dan waktu yang cukup terbatas (Fitriyani \& Rosalia, 2018).

Pada penelitian ini mengacu pada tahapan penelitian dan pengembangan yang terdiri dari analisis, desain, dan pengembangan. Pada tahap analisis yang dilakukan adalah melakukan analisis kebutuhan pembelajaran terkait kebutuhan guru serta materi yang sesuai dan mengacu pada masukan guru. Analisis kebutuhan dilakukan melalui angket, observasi oleh guru dan wawancara. Metode yang digunakan untuk wawancara yaitu kualitatif, kemudian untuk angket dan observasi oleh guru menggunakan metode kuantitatif. Selanjutnya, juga dilakukan langkah selanjutnya, yaitu studi literatur dalam rangka pencarian teori TGT serta kemampuan mengenal lambang bilangan yang relevan dengan masalah yang ditemukan di lapangan. Tahap ini merupakan tahap pra perencanaan yang meliputi: analisis kebutuhan, analisis karakteristik anak, dan analisis kebutuhan guru. Analisis yang digunakan adalah angket serta observasi guru yang menggunakan indikator seperti indikator di 
instrumen kemampuan mengenal lambang bilangan yang sudah divalidasikan oleh ahli instrumen.

Pada tahap desain, yang dilakukan adalah melakukan perencanaan atau merancang kegiatan yang sesuai dengan anak usia dini. Kemudian merancang istrumen yang terkait penilaian kelayakan produk, baik dari aspek materi, media, dan pedoman wawancara. Pedoman wawancara meliputi: (1) apa model yang digunakan di TK, (2) adakah model pembelajaran tambahan, (3) pengetahuan guru tentang TGT, (4) TGT dapat diunakan di PAUD atau tidak, (5) ketersedian APE, (6) gambaran kemampuan mengenal lambang bilangan di TK, (7) kebutuhan model pembelajaran untuk kemampuan mengenal lambang bilangan, (8) penggunaan LKA di TK.

Pada tahap pengembangan yang dilakukan adalah menghasilkan dan melakukan validas produk. Pada tahap ini, dilaksanakan expert judgment untuk ahli materi dan media dalam rangka melakukan identifikasi terhadap keberterimaan produk. Peluang bagi penelitian selanjutnya untuk mengimplementasikan dan menguji keefektifan produk, yaitu model pembelajaran kooperatif tipe TGT untuk membantu anak usia dini usia 4-5 tahun dalam mengenal lambang bilangan. Tahap pengimplementasian dapat diberikan untuk anak TK Kelompok A dengan usia 4-5 tahun. Tetapi untuk penetian ini hanya pada sampai tahap pengembangan, jadi untuk tahap pengimplementasian belum bisa dilakukan oleh peneliti.

Penelitian ini melibatkan ahli materi dan juga ahli media. Ahli materi berupaya untuk menguji dari isi buku panduan. Ahli materi merupakan individu yang memiliki kompetensi dan rekam jejak penelitian pada bidang anak usia dini, khususnya pada bidang pembelajaran kooperatif. Selain itu, ahli materi merupakan dosen Universitas Negeri Yogyakarta yang memiliki latar belakang Pendidikan Guru Pendidikan Anak Usia Dini. Ahli materi yang digunakan pada penelitian ini adalah 1 orang. Selanjutnya untuk ahli media, tujuannya untuk menilai buku panduannya yang meliputi cover, kegiatan yang digunakan, bahasa, huruf, grafika, dan warna. Ahli media merupakan individu yang memiliki rekam jejak penelitian pada pengembangan media pembelajaran, khususnya pada jenjang anak usia dini. Selain itu, ahli media merupakan dosen Universitas Negeri Yogyakarta yang memiliki latar belakang pendidikan Teknologi Pendidikan. Ahli media yang digunakan pada penelitian ini adalah 1 orang.

Instrumen yang digunakan dalam penelitian ini adalah lembar penilaian validasi instrumen, validasi materi, dan validasi media. Kisi-kisi instrumen yang digunakan untuk kemampuan mengenal lambang bilangan dapat dilihat pada tabel 1:

Tabel 1. Kisi-kisi Instrumen

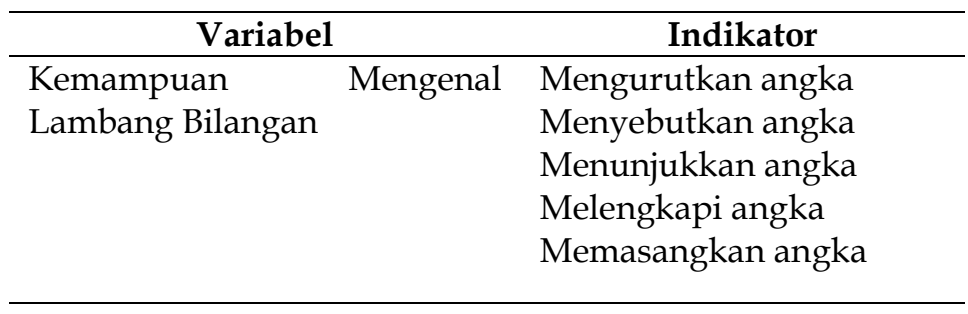

Kemudian untuk kriteria penilaian yang digunakan untuk expert judment dapat dilihat pada tabel 2:

Tabel 2. Kriteria Penilaian

\begin{tabular}{cc}
\hline Kriteria Penilaian & Skor \\
\hline Berkembang Sangat Baik (BSB) & 4 \\
Berkembang Sesuai Harapan (BSH) & 3 \\
Mulai Berkembang (MB) & 2 \\
Belum Berkembang (BB) & 1 \\
\hline
\end{tabular}


Kemudian untuk lembar validasi materi memuat aspek-aspek materi pembelajaran, bahasa serta penyajian dan sintaks atau langkah-langkah model pembelajaran kooperatif tipe TGT. Untuk detailnya dapat dilihat pada tabel 3:

Tabel 3. Lembar Validasi Materi

\begin{tabular}{cc}
\hline No & Aspek yang Dinilai \\
\hline 1. & Materi pembelajaran \\
2. & Bahasa serta penyajiannya \\
3. & Langkah-langkah model pembelajaran \\
\hline
\end{tabular}

Selanjutnya lembar penilaian media memuat aspek-aspek warna, huruf, grafika, ilustrasi, dan bahasa. Lebih detailnya dapat dilihat pada tabel 4:

Tabel 4. Lembar Validasi Media

\begin{tabular}{cc}
\hline No & Aspek yang Dinilai \\
\hline 1. & Warna \\
2. & Huruf \\
3. & Grafika \\
4. & Ilustrasi \\
5. & Bahasa \\
\hline
\end{tabular}

Sedangkan pedoman wawancara digunakan untuk mengidentifikasi pada observasi awal mengenai kemampuan mengenal lambang bilangan pada anak usia $4-5$ tahun. Pedoman wawancara dapat dilihat pada tabel 5:

Tabel 5. Pedoman Wawancara

\begin{tabular}{cl}
\hline No & \multicolumn{1}{c}{ Pertanyaan } \\
\hline 1. & Apa model pembelajaran yang digunakan? \\
2. & Apakah ada model pembelajaran tambahan? \\
3. & Apakah mengetahui tentang TGT? \\
4. & Apakah TGT dapat dilakukan di TK? \\
5. & Bagaimana ketersedian APE di TK? \\
6. & Bagaimana kemampuan mengenal lambang bilangan pada anak di TK? \\
7. & Apakah perlu model pembelajaran yang lain? \\
8. & Bagaimana penggunaan LKA di TK? \\
\hline
\end{tabular}

Teknik analisis data yang digunakan berupa data kuantitatif dan kualitatif. Data kualitatif digunakan untuk pedoman wawancara, kemudian untuk data kualitatif untuk angket guru, observasi oleh guru, hasil validasi materi, dan hasil validasi media. Skor yang diperoleh akan diubah menjadi data interval, diantaranya dapat dilihat pada tabel 6:

Tabel 6. Konversi Skor Kelayakan

\begin{tabular}{cll}
\hline No & \multicolumn{1}{c}{ Rentang Skor Kuantitatif } & \multicolumn{1}{c}{ Kriteria } \\
\hline 1. & $M i+1,5 \mathrm{Sd} i \leq \mathrm{X} \leq M i+3,0 \mathrm{Sd} i$ & Sangat Layak \\
2. & $M i+0 \mathrm{Sd} i \leq \mathrm{X} \leq M i+1,5 \mathrm{Sd} i$ & Layak \\
3. & $M i-1,5 \mathrm{Sd} i \leq \mathrm{X} \leq M i+0 \mathrm{Sd} i$ & Cukup \\
4. & $M i-3,0 \mathrm{Sd} i \leq \mathrm{X} \leq M i-3,0 \mathrm{Sd} i$ & Kurang \\
\hline
\end{tabular}

Teknik sampling menggunakan teknik purposive sampling, dimana sampel yang digunakan untuk observasi awal adalah seluruh anak TK Kelompok A di RA Al Amanah dengan jumlah 20 anak. Data kualitatif berup hasil dari validasi ahli terkait mdel pembelajaran 
kooperatif tipe TGT. Sedangkan Data kuantitatif digunakan untuk menganalisis angket validasi menggunakan skala likert. Pada pedoman penilaian yang digunakan skala 1-4, dengan kategori (1) sangat tidak setuju, (2) tidak setuju, (3) setuju, dan (4) sangat setuju.

\section{HASIL DAN PEMBAHASAN}

Penelitian ini memiliki tujuan untuk mengembangkan dan mengesahkan suatu produk dalam bidang pendidikan. Produk dalam penelitian ini adalah model pembelajaran kooperatif tipe teams Games Tournament (TGT) untuk anak usia 4-5 tahun. Untuk menjawab keberteriaan produk, penelitian ini menggunakan tahapan penelitian dan pengembangan mulai dari analisis, desain, dan pengembangan.

Pengambilan data kualitatif digunakan pada wawancara. Wawancara dilakukan untuk mengetahui seberapa besar kemampuan anak dalam mengenal lambang bilangan, serta model pembelajaran yang digunakan pada TK. Hasilnya mengatakan bahwa kemampuan mengenal lambang bilangan pada TK Al Amanah masih rendah, dan untuk model pembelajaran yang digunakan masih menggunkan sentra dan tidak ada model pembelajaran tambahan. Untuk pembelajaran mengenal lambang bilangan, sekolah masih sering menggunakan buku majalah dan LKA. Pengambilan data kuatitatif, diperoleh dari hasil angket observasi awal, hasil instrumen ahli materi dan ahli media. Skor yang diperoleh akan diubah menjadi data interval.

Pada tahap analisis, peneliti melakukan observasi awal tentang kemampuan mengenal lambang bilangan serta kegiatan yang dilakukan di TK. Pada kelompok A yang berjumlah 20 anak melalui angket yang diisi oleh guru kelas, dan dianlisis menggunakan metode kuantitatif. Kemudian untuk wawancara diambil menggunakan metode kualitatif dengan analisis deskriptif kualitatif. Temuan observasi awal adalah sebuah masalah mengenai kemampuan mengenal lambang bilangan yang rendah. Ditemukan banyak anak yang belum menghafal simbol dari lambang bilangan. Dibuktikan dengan ditemukannya 16 anak kurang mampu menyebutkan bilangan 1-10, 4 anak belum mengetahui lambang bilangan. Hal tersebut terlihat pada saat anak menuliskan lambang bilangan setelah membilang banyak benda sesuai penjelasan guru. Dan ketika anak menghubungkan jumlah benda dan menariknya dengan menarik garis ke bilangan yang sesuai, ditemukan banyak anak yang belum benar. Sebagai contoh anak sudah membilang dengan benar gambar dengan jumlah 7, tapi menarik garisnya dihubungkan ke angka 5. Data tersebut diambil melalui angket dan observasi oleh guru. Angket berisikan indikator yang telah divalidkan oleh ahli instrumen. Sedangkan observasi dilakukan oleh guru untuk menilai dari indikator yang telah ditetapkan. Dari hasil wawancara, hasilnya mengatakan bahwa kemampuan mengenal lambang bilangan pada TK Al Amanah masih rendah, dan untuk model pembelajaran yang digunakan masih menggunkan sentra dan tidak ada model pembelajaran tambahan. Untuk pembelajaran mengenal lambang bilangan, sekolah masih sering menggunakan buku majalah dan LKA. Dari masalah tersebut, peneliti menggunakan model pembelajaran yang menarik dan anak akan merasa tertantang karena menggunakan kegiatan melalui pertandingan. Model pebelajaran tersebut yaitu model pembelajaran kooperatof tipe TGT.

Pada tahap perencanaan, peneliti merancang sebuah kegiatan mengenai lambang bilangan menggunakan model pembelajaran kooperatif tipe TGT. Kegiatan selanutnya adalah merancang sebuah instrumen yang divalidasikan oleh seorang ahli instrumen dibidang kognitif. Kemudian, kegiatan berikutnya merancang sebuah produk yaitu model pembelajaran TGT yang dikemas dalam buku panduan, yang akan dipergunakan guru untuk melaksanakan model pembelajaran kooperatif tipe TGT. Produk tersebut divalidasikan oleh validator materi dan validator media, agar mempermudah guru dalam menangkap dan memahami buku panduan tersebut. Pada gambar 1 adalah sampul buku panduan, sebagai berikut: 


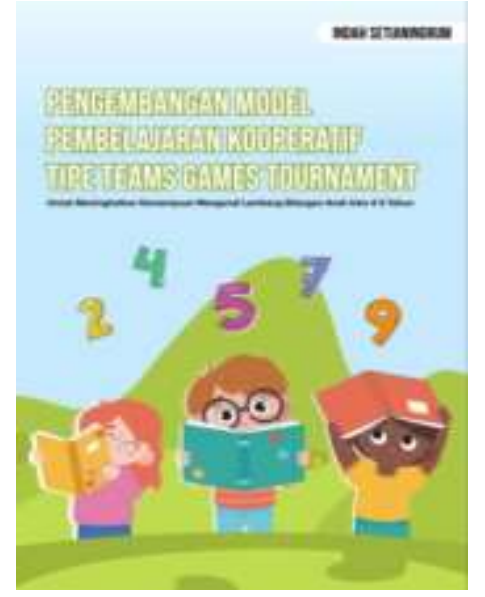

\section{Gambar 1 Sampul Buku Panduan}

Pada tahap pengembangan, kegiatannya adalah mengitung jumlah presentase dari penilaian instrumen validasi materi serta validasi media. Pada validasi materi diperoleh $84,37 \%$. Maka kesimpulan dari validasi terhadap istrumen penilaian dapat dikategorikan sangat valid, seperti pada tabel 7 berikut.

Tabel 7. Hasil Penilaian Validator Ahli Materi

\begin{tabular}{ccl}
\hline Aspek Validasi & Presentase (\%) & Kategori \\
\hline Materi pembelajaran & $90,62 \%$ & Sangat Valid \\
Sintkas atau langkah-langkah & $87,50 \%$ & Sangat Valid \\
pembelajaran kooperatif tipe TGT & $75,00 \%$ & Valid \\
Bahasa dan penyajian & 84,37 & Sangat Valid \\
\hline Rata-rata &
\end{tabular}

Hasil presentase praktikalitas instrumen penilaian oleh ahli media secara kelseluruhan adalah $87,15 \%$. Maka kesimpulan dari validator media dapat dikategorikan sangat Valid, seperti pada tabel 8 berikut.

Tabel 8. Hasil Penilaian Validasi Media

\begin{tabular}{ccc}
\hline Aspek Validasi & Presentase (\%) & Kategori \\
\hline Grafika & $83,33 \%$ & Sangat Valid \\
Warna & $100 \%$ & Sangat Valid \\
Huruf & $75,00 \%$ & Sangat Valid \\
Struktur buku & $83,33 \%$ & Sangat Valid \\
Bahasa & $87,50 \%$ & Sangat Valid \\
Ilustrasi & $93,75 \%$ & Sangat Valid \\
\hline Rata-rata & $87,15 \%$ & Sangat Valid \\
\hline
\end{tabular}

Hasil dari penelitian merupakan produk dari model pembelajaran kooperatif tipe TGT untuk meningkatkan kemampuan mengenal lambang bilangan yang dikategorikan sangat valid atau memiliki keberterimaan tinggi untuk diterapkan di lembaga PAUD. Penerapan model pembelajaran ini memiliki signifikasi terhadap peningkatkan kemampuan mengenal lambang bilangan, apabila guru selanjutnya dapat melakukan tahap demi tahap dari model pembelajaran ini. Kreatifitas guru dalam mengimplementasikan model pembelajaran menjadi nilai tambah terhadap keefektifan model pembelajaran guna mengembangkan kemampuan mengenal lambang bilangan anak. Penelitian ini menggunakan pengembangan ADDIE hanya sampai tahap ketiga saja, yaitu tahap analisis, tahap perencanaan, dan tahap pengembangan. Untuk tahap selanjutnya yaitu tahap implementasi dan evaluasi tidak bisa dilanjutkan karena 
sulitnya medapatkan surat zin penelitian di Lembaga TK. Dengan demikian,maka penelitian tidak bisa diuji cobakan ke lapangan karena kondisi saat ini dalam kondisi pandemi Covid-19. Maka untuk hasil pre test dan post test tiak dapat dilakukan karen belum sampai pada tahap implementasi. TGT sendiri harus dilakukan dengan pembelajaran langsung, tidak bisa dengan pembelajaran daring. Literatur lain menyebutkan bahwa praktik kreatif guru anak usia dini menjadi salah satu unsur yang memiliki peran sentral untuk meningkatkan keberhasilan proses pembelajaran mencapai tujuan (Cheung, 2012a, 2012b; Yates \& Twigg, 2017; Yildirim, 2010).

Ketergantungan terhadap tenaga pengajar yang masih mendominasi sikap anak, khususnya dalam bidang pengembangan kognitif perlu diupayakan metode pembelajaran yang mendorong anak untuk lebih aktif, kreatif, tertantang dan menyenangkan dalam belajar (Dewi et al., 2014). Peran guru dalam mendidik, tidak hanya memberikan pengetahuan kepada anak, melainkan membantu membangun pengetahuannya sendiri melalui pengalaman belajar. Hal tersebut didukung dengan adanya penelitian terdahulu yang telah membuktikan secara empiris bahwa dengan menggunakan model pembelajaran tipe Teams Games Tournament (TGT) dapat memberi pengaruh yang besar terhadap tingginya hasil belajar siswa (Novitasari dkk., 2019; Veloo \& Chairhany, 2013; Wyk, 2011). Hasil-hasil penelitian terdahulu tersebut menjadi salah satu dasar melakukan modifikasi sebuah model pembelajaran kooperatif tipe TGT yang lebih kreatif dan inovatif untuk meningkatkan kemampuan mengenal lambing bilangan. Dengan adanya model pembelajaran yang efektif, maka anak akan tertarik dengan pembelajaran yang diberikan oleh guru.

Model pembelajaran adalah semua hal yang dapat membantu memudahkan anak dalam memperoleh pengetahuan, keterampilan dan menentukan sikap (Latif dkk., 2013). Tetapi banyak masalah pada lembaga TK yang memiliki permasalah untuk kemampuan mengenal lambang bilangan. Anak belajar mengucapkan angka 1-10 dengan senandung angka. Dengan bersenandung angka lebih mudah anak dalam menyebutkan angka 1-10 (Beaty, 2013). Saat anak berhitung, tanpa disadari terkadang salah dalam mengurutkan angka, namun kesalahan ini tidak diketahui oleh anak (Zughoiriyah dkk., 2015). Dari permasalah yang ada dipelukannya model pembelajaran yang inovatif agar dapat maksimal memberikan pembelajaran untuk anak. Dengan adanya model pembelajaran kooperatif tipe TGT ini, maka dapat diberikan pada anak agar kemampuan mengenal lambang bilangan dapat meningkatkan perkembangan anak.

Identifikasi terhadap kelayakan dari model pembelajaran kooperatif tipe TGT dilakukan tidak pertama kali dilakukan. Penelitian terdahulu juga menunjukkan bahwa model pembelajaran kooperatf tipe TGT menjadi salah satu model pembelajaran yang dapat digunakan untuk meningkatkan kemampuan kognitif anak (Akçay, 2016; Kristiana dkk., 2017; Navarro-Pablo \& Gallardo-Saborido, 2015). TGT sendiri menjadi salah satu tipe pembelajaran kooperatif yang layak dan kompatibel untuk anak usia dini. Sebagai buktinya, kooperatif learning dapat digunakan secara efektif untuk meningkatkan kemampuan anak usia dini dalam memahami materi tentang organ tubuh manusia (Akçay, 2016). Pembelajaran kooperatif secara luas diakui sebagai praktik pedagogis yang mempromosikan sosialisasi dan pembelajaran di antara siswa pada taman kanak-kanak, salah satunya untuk membantu mempromosikan pemahaman pada bidang matematika (Gillies, 2014). Hal tersebut, menjadi salah satu dasar dilaksanakan penelitian dan pengembangan ini, akan tetapi pada penelitian ini secara spesifik mengidentifikasi keberterimaan model pembelajaran tipe TGT untuk meningkatkan kemampuan mengenal lambing bilangan anak usia dini sebagai salah satu aspek kemampuan kognitif anak usia dini.

TGT sebagai salah satu tipe model pembelajaran kooeperatif dapat memfasilitasi siswa untuk belajar sambil berinteraksi dan bersosialisasi dengan teman-temannya untuk mengenal lambang bilangan. Beberapa penelitian menunjukkan bahwa proses dinamika interaksi dalam pembelajaran kooperatif dapat memfasilitasi anak dalam perkembangan kemampuam matematis (Astuti, 2015). Lebih jauh, pembelajaran kooperatif dengan tipe permainan dapat 
membantu meningkatkan ketertarikan dan kemampuan anak usia dini dalam meningkatkan kapabilitas kognitifnya (Suryaningsih \& Rimpiati, 2018), yang mana salah satu kapabilitas kognitif anak usia dini adalah kemampuan mengenal lambang bilangan. Selain itu, pembelajaran kooperatif memfasilitasi anak untuk belajar bekerjasama untuk mengikuti proses diskusi mengenai materi tertentu (Suryaningsih, 2020), yang dalam penelitian ini difokuskan pada tipe TGT untuk mengembangkan kemampuan mengenal lambang bilangan.

Model pembelajatan kooperatif tipe TGT sebagai produk pada penelitian ini menggunakan tujuh tahapan, yaitu presentasi kelas, tim, game, apersepsi aturan main, turnamen, rekognisi tim, dan evaluasi (Slavin, 2010). Tahapan ini termuat pada buku panduan yang dapat menjadi pedoman guru dalam mengaplikasikan model pembelajaran kooperatif tipe TGT untuk membantu meningkatkan kemampuan mengenal lambang bilangan anak usia dini. Buku panduan ini memiliki kelebihan pada penyesuaian sasaran anak usia dini, yang pada penelitian ini spesifik untuk anak usia 4 - 5 tahun.

Hasil penelitian ini menunjukkan bahwa produk penelitian memiliki keberterimaan tinggi berdasarkan penilaian ahli materi dan media, memiliki peluang bagi pelaksanaan penelitian selanjutnya. Salah satu peluang penelitian selanjutnya adalah melakukan uji efektifitas model pembelajaran ini untuk meningkatkan kemampuan kognitif terkhusus kemampuan mengenal lambang bilangan. Uji efektifitas dilakukan untuk menentukan apakah model pembelajaran kooperatif tipe TGT memberikan efek terhadap perbedaan tingkat kemampuan mengenal lambang bilangan sebelum dan sesudah dilakukan perlakuan. Selain itu, penelitian selanjutnya juga memungkinkan untuk mengembangkan sebuah produk berupa model pembelajaran kooperatif tipe TGT bermuatan budaya lokal tertentu untuk mengembangkan kemampuan tertentu pada anak usia dini.

\section{SIMPULAN}

Anak usia dini memiliki kemampuan mengenal lambang bilangan yang berbeda antara satu dengan yang lainnya. Anak memiliki masalah mengenal lambang bilangan apabila belum menghafal simbol dari lambang bilangan. Sehingga membutuhkan kreatifitas dari guru dalam merancang strategi pembelajaran yang dapat memberdayakan anak dalam mengenal lambing bilangan. Penelitian ini berupaya untuk menjawab hal tersebut dengan mengembangkan model pembelajaran kooperatif tipe TGT untuk membantu anak mengenal lambang bilangan. Berdasarkan penilaian ahli materi dan media, produk penelitian memiliki keberterimaan sangat tinggi untuk diimplementasikan pada anak usia dini dalam membantu mengenal lambang bilangan. Hasil penelitian ini seyogyanya menjadi peluang bagi penelitian selanjutnya untuk mengidentifikasi secara empiris keefektifan model pembelajaran kooperatif tipe TGT untuk meningkatkan kemampuan anak usia dini mengenal lambang bilangan.

\section{UCAPAN TERIMAKASIH}

Selesainya penelitian ini tidak terlepas dari dukungan beberapa pihak. Salah satu pihak yang memberikan dukungan pada selesainya penelitian ini adalah jajaran pimpinan dan dosen program pascasarjana Penddikan Guru Pendidikan Anak Usia Dini Universitas Negeri Yogyakarta yang telah memberikan kesempatan dan peluang dalam melaksanakan penelitian. Selain itu, diucapkan terima kasih pada tim ahli, baik dari ahli materi dan media yang telah memberikan dukungan dan arahan untuk perbaikan produk penelitian ini. Tak lupa ucapan terima kasih kepada Kepala Sekolah RA Al Amanah dan guru kelas Kelompok A. Serta anak-anak Kelompok A yang telah mengikuti penelitian pada observasi awal.

\section{DAFTAR PUSTAKA}

Akçay, N. O. (2016). Implementation of Cooperative Learning Model in Preschool. Journal of Education and Learning, 5(3), 83-93. https://doi.org/10.5539/jel.v5n3p83 
Al Mubarok, A. A. S., \& Amini, A. (2019). Kemampuan Kognitif dalam Mengurutkan Angka melalui Metode Bermain Puzzle Angka. Jurnal Obsesi: Jurnal Pendidikan Anak Usia Dini, $4(1)$,

77-89. https:// doi.org/10.31004/obsesi.v4i1.221

Astuti, A. (2015). Pengaruh Pendekatan Problem Posing dengan Model Pembelajaran Kooperatif Tipe Stad terhadap Kemampuan Komunikasi Matematis Siswa Kelas XII SMA Negeri 1 Salo Kabupaten Kampar. Jurnal Obsesi: Jurnal Pendidikan Anak Usia Dini, 1(1), 1-11.

Beaty, J. J. (2013). Observasi Perkembangan Anak Usia Dini (Edisi ketujuh). Jakarta: Kencana. Black, M. M., Walker, S. P., Fernald, L. C., Andersen, C. T., DiGirolamo, A. M., Lu, C., McCoy, D. C., Fink, G., Shawar, Y. R., \& Shiffman, J. (2017). Early childhood development coming of age: Science through the life course. The Lancet, 389(10064), 77-90. https:// doi.org/10.1016/S0140-6736(16)31389-7

Britto, P. R., Lye, S. J., Proulx, K., Yousafzai, A. K., Matthews, S. G., Vaivada, T., PerezEscamilla, R., Rao, N., Ip, P., \& Fernald, L. C. (2017). Nurturing care: Promoting early childhood development. The Lancet, 389(10064), 91-102. https:// doi.org/10.1016/S0140-6736(16)31390-3

Carpenter, H. (2012). Secret gardens: A study of the golden age of children's literature. Faber \& Faber.

Cheung, R. H. P. (2012a). Teaching for creativity: Examining the beliefs of early childhood teachers and their influence on teaching practices. Australasian journal of early childhood, 37(3), 43-52. https:// doi.org/10.1177/183693911203700307

Cheung, R. H. P. (2012b). Teaching for creativity: Examining the beliefs of early childhood teachers and their influence on teaching practices. Australasian journal of early childhood, 37(3), 43-52. https:/ / doi.org/10.1177/183693911203700307

Dewi, A. K., Pudjawan, K., \& Sudatha, I. G. W. (2014). Penerapan model pembelajaran kooperatif teams games tournament berbantuan media kotak pos geometri untuk meningkatkan perkembangan kognitif anak. e-Journal PG-PAUD Universitas Pendidikan Ganesha, 2(1).

Gillies, R. M. (2014). Cooperative learning: Developments in research. International Journal of Educational Psychology, 3(2), 125-140.

Hasibuan, M. (2020). Penggunaan Media Kartu Angka Dalam Upaya Meningkatkan Kemampuan Mengenal Angka Pada Anak Usia Dini. PAUDIA: Jurnal Penelitian dalam Bidang Pendidikan Anak Usia Dini, 9(2), $62-70$. https:// doi.org/10.26877/paudia.v9i2.6736

Kogan, N. (2013). Cognitive styles in infancy and early childhood (Psychology Revivals). Psychology Press. https:// doi.org/10.4324/9780203795811

Kristiana, I., Nurwahyunani, A., \& Dewi, E. R. S. (2017). Pengaruh Model Pembelajaran TGT Menggunakan Media Puzzle Terhadap Keaktifan Dan Hasil Belajar Kognitif Siswa Pada Materi Sistem Ekskresi Siswa Kelas VIII MTs N 1 Semarang. Bioma: Jurnal Ilmiah Biologi, https://doi.org/10.26877/bioma.v6i2.1740

$6(2)$.

Latif, M., Zukhairina, Zubaidah, R., \& Afandi, M. (2013). Orientasi baru pendidikan anak usia dini: Teori dan aplikasi. Jakarta: Prenada Media group.

Lazarus, J. H., Bestwick, J. P., Channon, S., Paradice, R., Maina, A., Rees, R., Chiusano, E., John, R., Guaraldo, V., \& George, L. M. (2012). Antenatal thyroid screening and childhood cognitive function. New England Journal of Medicine, 366(6), 493-501. https:// doi.org/10.1056/NEJMoa1106104

Navarro-Pablo, M., \& Gallardo-Saborido, E. J. (2015). Teaching to training teachers through cooperative learning. Procedia-Social and behavioral sciences, 180, 401-406. https://doi.org/10.1016/j.sbspro.2015.02.136 
Novitasari, L., Mintarti, S. U., \& Soesilo, Y. H. (2019). Combining Teams Games Tournament (TGT) and Mind Mapping to Improve Students' Activity and Learning Achievement. Classroom Action Research Journal (CARJO), 3(1), 16-23.

Olusanya, B. O., Sirimanna, T., \& McPherson, B. (2017). Timely sensory stimulation and early childhood development. The Lancet, 390(10113), 2626. https://doi.org/10.1016/S0140$\underline{6736(17) 32410-8}$

Penn, H. (2014). Understanding early childhood. McGraw-Hill Education (UK).

Prasetiawan, H., \& Supriyanto, A. (2016). Guidance and counseling comprehensif program in early childhood education based on developmental task. Jurnal CARE (Children Advisory Research and Education), 3(3), 95-103.

Saloko, A., Sari, D. Y., \& Novrizar, J. (2019). Karakteristik kurikulum tingkat satuan pendidikan (KTSP) yang memuat aspek pengembangan moral, sosial dan emosional anak. INCLUSIVE: Journal of Special Education, 4(1).

Slavin, R. E. (2010). Cooperative Learning (Teori, Riset dan Praktik) (N. Yusron, Penerj.). Bandung: Nusa Media.

Sriningsih, N. (2009). Pembelajaran Matematika Terpadu untuk Anak usia Dini. Bandung: Pustaka Sebelas.

Suciyati, S., \& Masrita, M. (2020). Kemampuan Siswa Pendidikan Anak Usia Dini Dalam Mengenal Bilangan. Journal of Basic Education Research, 1(1), 36-40.

Sujiono, Y. N., \& Sujiono, B. (2012). Konsep Dasar Pendidikan Anak Usia Dini. Jakarta: PT Indeks.

Sumardi, S., Rahman, T., \& Gustini, I. S. (2017). Peningkatan Kemampuan Anak Usia Dini Mengenal Lambang Bilangan Melalui Media Playdough. Jurnal PAUD Agapedia, 1(2), 190-202.

https://doi.org/10.17509/jpa.v1i2.9359

Suryaningsih, A. (2020). Pengaruh Penerapan Pembelajaran Kooperatif Tipe Jigsaw terhadap Perilaku Kesehatan dan Keselamatan Anak. Jurnal Obsesi: Jurnal Pendidikan Anak Usia Dini, 5(2), 1063-1072. https:// doi.org/10.31004/obsesi.v5i2.751

Suryaningsih, A., \& Rimpiati, N. L. (2018). Implementation of Game-Based Thematic Science Approach in Developing Early Childhood Cognitive Capabilities. Jurnal Obsesi: Jurnal Pendidikan Anak Usia Dini, 2(2), 194-201. https://doi.org/10.31004/obsesi.v2i2.113

Susanto, A. (2011). Perkembangan Anak Usia Dini. Jakarta: Kencana Prenada Media Group.

Veloo, A., \& Chairhany, S. (2013). Fostering students' attitudes and achievement in probability using teams-games-tournaments. Procedia-Social and Behavioral Sciences, 93, 59-64. https://doi.org/10.1016/j.sbspro.2013.09.152

Wyk, M. M. van. (2011). The effects of Teams-Games-Tournaments on achievement, retention, and attitudes of economics education students. Journal of Social Sciences, 26(3), 183193.

https://doi.org/10.1080/09718923.2011.11892895

Yates, E., \& Twigg, E. (2017). Developing creativity in early childhood studies students. Thinking Skills and Creativity, 23, 42-57. https://doi.org/10.1016/j.tsc.2016.11.001

Yildirim, A. (2010). Creativity in early childhood education program. Procedia-Social and Behavioral Sciences, 9, 1561-1565. https:// doi.org/10.1016/j.sbspro.2010.12.365

Zughoiriyah, B., Sulastri, N. M., \& Tirtayani, L. A. (2015). Penerapan teams games tournament berbantuan media kartu domino angka untuk meningkatkan kemampuan mengenal lambang bilangan, Journal PG PAUD Universitas Pendidikan Ganesha Jurusan Pendidikan Guru Pendidikan Anak Usia Dini. e-Journal PG PAUD Universitas Pendidikan Ganesha, 3(1). 